\title{
Evaluation of the Impact of Best Management Practices on Streamflow, Sediment and Nutrient Yield at Field and Watershed Scales
}

\author{
Avay Risal ${ }^{1} \cdot$ Prem B. Parajuli $^{1}$ (iD
}

Received: 26 May 2021 / Accepted: 21 January 2022 / Published online: 5 February 2022

(c) The Author(s) 2022

\begin{abstract}
Evaluating Best Management Practices (BMPs) in watersheds using hydrologic and water quality models can help to establish an effective watershed water management. Soil and Water Assessment Tool (SWAT) was applied to Big Sunflower River Watershed (BSRW) and the Stovall Sherard Watershed (SSW) to evaluate BMP's impact at watershed and field scale watersheds respectively. SWAT was calibrated and validated for streamflow, sediment yield, total nitrogen (TN), and total phosphorous (TP) at outlets of three sub-basins of the BSRW, and within the SSW. BMP scenarios of check-dam, tail water pond, vegetative filter strips (VFS), nutrient management, and tillage management were evaluated for their efficacy in reducing streamflow, sediment yield, and nutrient loads at field and watershed scales. The VFS was determined as the most effective BMP in decreasing sediment yield, $\mathrm{TN}$, and TP at both field and watershed scales. At field scale, reduction of sediment yield, TN, and TP by VFS ranged from 8 to $12 \%, 71 \%$ to $98 \%$, and $72 \%$ to $99 \%$ respectively and at watershed scale, reduction of sediment yield, TN, and TP by VFS ranged from 12 to $38 \%, 29 \%$ to $87 \%$, and $42 \%$ to $99 \%$ respectively. The application of conservation and zero tillage operation showed reduction in sediment yield by $1 \%$ to $2 \%$ respectively but increased TN and TP by $2 \%$ to $25 \%$ at field and watershed scale watersheds. This study will help in managing water at field and watershed scale watersheds regarding BMPs selection and implementation.
\end{abstract}

Keywords Watershed $\cdot$ Best management practices $\cdot$ SWAT $\cdot$ Water quality $\cdot$ Nutrients

\section{Introduction}

In United States, agricultural operation is considered one of the main cause of pollution in rivers, streams, and others (Mateo-Sagasta et al. 2017). Chemical fertilizer may help to increase crop yield but degrade surface-ground water, when applied excessive quantity (Lory 2018). Approximately 11 billion kilograms of nitrogen are applied to

Prem B. Parajuli

pparajuli@abe.msstate.edu

1 Department of Agricultural and Biological Engineering, Mississippi State University, 130

Creelman St., Mail Box: 9632, Mississippi State, MS 39762, US 
agricultural fields in US, in which about fifty percent is drained to water (Capel et al. 2018). Nutrients transport from agricultural fields are responsible for water quality degradation and causing eutrophication and harmful algal bloom (Sharpley and Wang 2014; Bhandari et al. 2017). Pollution caused by nutrients can be reduced through implementation of BMPs. Water and nutrient transport processes at field and watershed scales could be understood through modeling approach along with field monitoring (Kumar et al. 2019; Borrelli et al. 2021). Several studies have utilized SWAT model to evaluate effects of BMPs at field and watershed scales (Saleh et al. 2000; Santhi et al. 2001; Gitau et al. 2008; Daggupati et al. 2011; Dakhlalla and Parajuli, 2015; Dakhlalla et al. 2016; Merriman et al. 2018; Uribe et al. 2018; Li et al. 2021; Preetha et al. 2021).

BMPs were found effective in reducing $\mathrm{N}_{-} \mathrm{NO}_{3}$ from surface runoff and groundwater from the Carapelle river basin, Southern Italy (Ricci et al. 2022). The output of a watershed scale SWAT model was applied to the field scale SWAT model to evaluate the impact of BMPs in the Black Kettle Creek watershed in Arkansas River watershed (Daggupati et al. 2011). SWAT model was applied to a field scale watershed in Michigan determined that zero tillage with cover crop can reduce nitrate while VFS can reduce sediment yield and phosphorus (Merriman et al. 2018). Conservation tillage applied in the Fuquene Lake watershed, demonstrated reduction of sediment yield and surface runoff by $26 \%$ and $11 \%$ respectively, while TN and TP were increased by $2 \%$ and $18 \%$ respectively (Uribe et al. 2018). Some BMPs were evaluated using SWAT model at watershed scale in the Big Sunflower River Watershed (BSRW), Mississippi (Parajuli et al. 2013; Risal and Parajuli 2019). However, BMPs evaluation for streamflow, and water quality at field scale watershed in Mississippi are limited. Efficacy of BMPs at field scale could be different than at watershed scale. This study evaluated the effect of BMPs at field and watershed scales simultaneously that has not yet been conducted in Mississippi, which could be a new contribution. The objectives of this study were to: (a) develop a watershed and field-scale SWAT models; (b) calibrate and validate SWAT models for stream-flow, sediment, TN, and TP; and (c) evaluate the impact of BMPs on streamflow, sediment, and nutrient yield.

\section{Methodology}

\subsection{Study Area}

The BSRW (drainage area of $10,500 \mathrm{~km}^{2}$ ), located at the Mississippi River alluvial plain (Mississippi Delta), and SSW (drainage area of $120 \mathrm{~km}^{2}$ ), located within the BSRW, were selected for BMPs impact evaluation at watershed and field scale watersheds respectively. Elevation of BSRW ranged from 15 to $60 \mathrm{~m}$ above mean sea level and that of SSW ranged from 45 to $55 \mathrm{~m}$. BSRW was covered by cropland (70\%); wetlands/forest (15\%); and pasture, urban, and others (15\%), (Parajuli et al. 2013; Risal and Parajuli 2019). SSW was covered by cropland (87\%); and urban, pasture and other crops (13\%). Major soil types of BSRW were Alligator, Dowling, Dundee, Forestdale, and Sharkey and that for SSW were Dowling, Dundee, and Sharkey. Average annual temperature for both BSRW and SSW was $18{ }^{\circ} \mathrm{C}$ with average annual precipitation of 1,371 mm (Ouyang, 2012). Location of BSRW and SSW along with USGS gauges, weather stations, and monitoring stations is shown in Fig. 1. 


\section{Location of Big Sunflower River Watershed and Stovall Sherard Watershed}

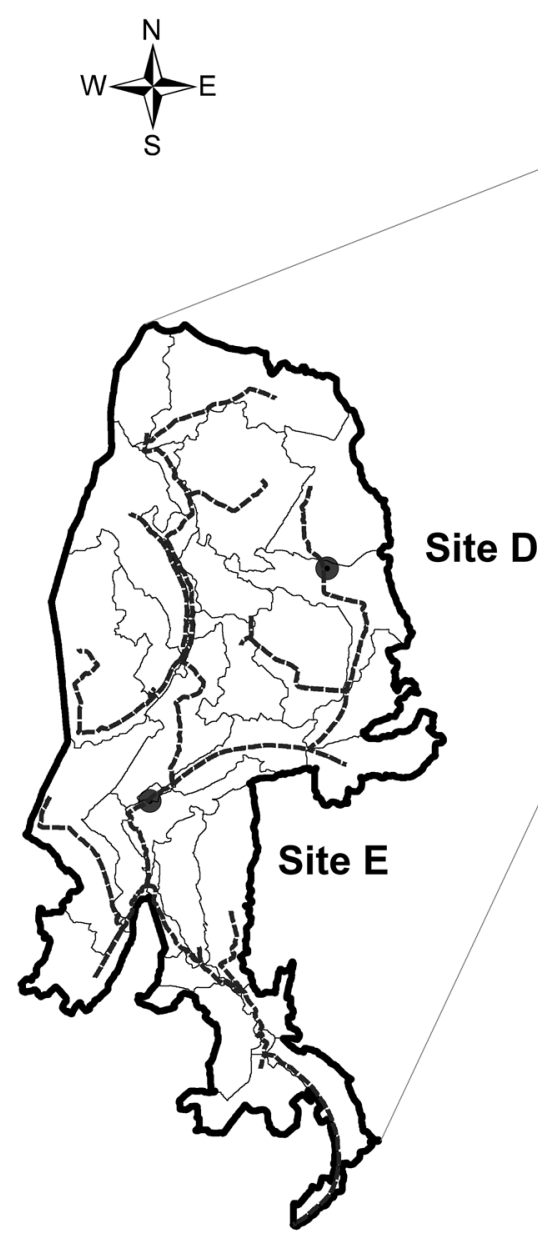

Stovall Sherard Watershed

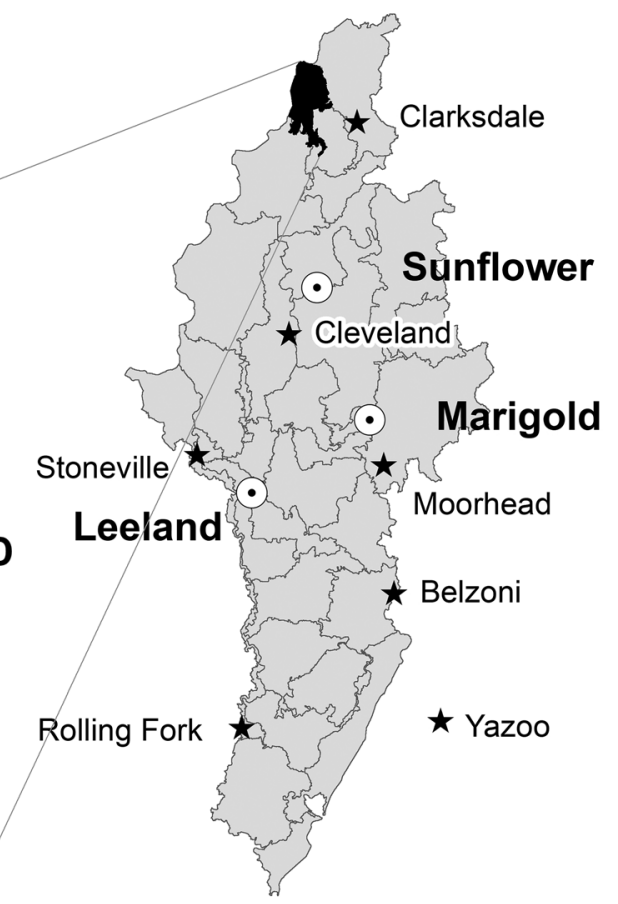

Big Sunflower River Watershed

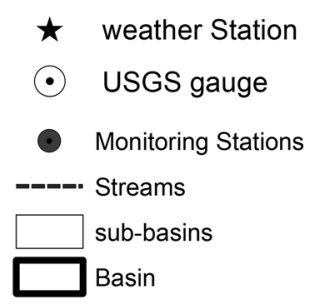

50 100

Kilometers

Fig. 1 Location of Big Sunflower River Watershed, Stovall Sherard Watershed (field scale), weather stations, USGS gauges, and monitoring site for calibration of sediment and nutrients

\subsection{SWAT Model}

Soil and Water Assessment Tool (SWAT) is a comprehensive and variable time steps model that can be used to simulate management practices on water quality and quantity 
from both field and watershed scale (Neitsch et al. 2002). Previous literatures utilized SWAT model to assess BMPs impact on hydrology and water quality (Gitau et al. 2008; Merriman et al. 2018; Ni and Parajuli 2018). ArcGIS extension and interface version of SWAT (ArcSWAT 2019) was used in this study to delineate and calculate watershed input parameters including sub-watersheds, drainage network. In this study model was developed using input data from various sources such as Digital Elevation Model (DEM-USGS, 2020), land use and land cover (LULC-NASS 2018), soil (SSURGO 2020), and weather (NOAA 2019). Other watershed related management data including planting, harvesting, irrigation, and tillage were utilized from Mississippi Agricultural And Forestry Experiment Station (MAFES 2019).

\subsection{Calibration and Validation}

Sequential Uncertainty Fitting (SUFI-2) algorithm within SWAT auto calibration tool: SWAT Calibration and Uncertainty Procedures (SWAT-CUP) (Abbaspour 2013) was used for calibration and validation for both field and watershed scale watersheds. Monthly streamflow calibration (2005-2010) and validation (2011-2016) of the BSRW utilized the USGS gage data from Marigold, Sunflower and Leland (Risal and Parajuli 2019). Similarly, model was calibrated (2013-2014) and validated (2015-2016) for daily sediment, TN and TP yields using data from Marigold, Sunflower, and Leland gage stations (Risal and Parajuli 2019). Monthly streamflow calibration (2006-2011) and validation (2012-2017) of the SSW was conducted at the outlet of SSW, located at the outlet of sub-basin 2 of the BSRW. Similarly, daily sediment, TN, and TP yields calibration and validation were conducted at site D and E respectively using daily observed data from 2014 to 2016. Sensitivity of the parameters for both field and watershed scales models were assessed using t-statistics, degree of sensitivity and p-value, showing the significance of sensitivity within SWAT-CUP (Gyamfi et al. 2016).

\subsection{BMP Application Scenarios}

Check dams, VFS, tail water ponds, nutrient management, and tillage management BMPs were selected in this study to evaluate their impact on streamflow and water quality at field and watershed scales.

\subsubsection{Check Dams}

Check dams were simulated using a conceptual pond module in the SWAT model (Arnold et al. 2012). The parameters, fraction of sub-basin draining into pond (PND-FR), surface area of pond when filled to principle spillway (PND_PSA), volume of water needed to fill pond to the principle spillway (PND_PVOL), initial volume of water in pond (PND_VOL), nitrogen settling rate in pond (NSETLP), phosphorous settling rate in pond (PSETLP) and number of days to reach target storage (NDTARG) were adjusted for the evaluation of effect of check dam at the BSRW and SSW, and equivalent ponds of varying dimension and parameters were placed at the outlet of each sub-basins according to the actual length of reach in the respective sub-watershed. 


\subsubsection{Vegetative Filter Strip}

Effect of VFS width in reduction of nutrient yield was simulated by adjusting width of filter strip edge (FILTERW) in SWAT. Filter strip widths of 10, 20 and $30 \mathrm{~m}$ were used in this study to evaluate their effect on improving water quality. The fraction of total runoff from entire field entering the most concentrated $10 \%$ of vegetative filter strip (VFSCON) was set to 0.5 , field area to VFS area ratio (VFSRATIO) was set to 50, and fraction of flow through the most concentrated $10 \%$ of channelized VFS (VFSCH) was set to 0 (Waidler et al. 2011).

\subsubsection{Tail Water Pond}

Tail water ponds were simulated using conceptual pond module in the SWAT model to assess effectiveness of tail water pond at watershed scale. According to actual surface area of existing open water in each sub-basin of the BSRW, equivalent pond areas of varying dimension and parameters were placed at outlet of each sub-basin. For field scale watershed, open water in the SSW was digitized and the surface area of open water was used as an equivalent surface area of the tail water pond that are placed at three sub-basins of the SSW. The average depth of tail water pond was considered to be $3 \mathrm{~m}$ (NRCS 1997). The location of the open water in the SSW along with their surface area is shown in Table 1.

Effect of tail water ponds in reducing nutrients was evaluated by adjusting parameters: fraction of sub-basin draining into pond (PND-FR), surface area of pond when filled to principal spillway (PND_PSA), volume of water needed to fill pond to the principal spillway (PND_PVOL), initial volume of water in pond (PND_VOL), nitrogen settling rate in pond (NSETLP), phosphorous settling rate in pond (PSETLP), and number of days to reach target storage (NDTARG).

\subsubsection{Nutrient Management}

Water quality improvement can be achieved through a reduction of excessive nutrient runoff from agricultural watersheds. Nutrient management may include: amount, time, and application method of manure and fertilizers. This study considered reduction in amount of nitrogen and phosphorous application at BSRW and SSW. Most of the fields in the SSW were cultivated with soybean. Since soybean can utilize atmospheric nitrogen required for plant growth, nitrogen fertilizer was not applied during the cultivation period of soybean (Deibert et al. 1979). Effects of fertilizer reduction rates regarding nitrogen and phosphorus loads were assessed for watershed scale study and reduction in only phosphorus loads was assessed for field scale study. Recommended amount of elemental nitrogen and phosphorous was applied to crop field during spring before planting season as a base scenario and other scenarios were developed by reducing the amount of fertilizers by $10 \%, 20 \%$, and $30 \%$ in order to assess their effects in water quality.

Table 1 Location and surface area of tail water ponds located in the SSW

\begin{tabular}{lcl}
\hline Open water & Surface area (hector) & Sub-basin \\
\hline Pond A & 7.1 & 5 \\
Pond B & 1.3 & 12 \\
Pond C & 24.5 & 20 \\
\hline
\end{tabular}




\subsubsection{Tillage Management}

Water quality can be affected by adaptation of tillage managements. Conventional, conservation, and zero tillage management practices were developed using the SWAT model to assess water quality improvements from both field and watershed scales. The depth and mixing efficiency for the tillage operations considered in this study are given in Table 2 (Tripathi et al. 2005).

\section{Results}

\subsection{Calibration and Validation}

The $\mathrm{R}^{2}$ and NSE for monthly streamflow calibration of SSW at watershed outlet were 0.77 and 0.64 respectively; and that for validation were 0.81 and 0.72 respectively. Similarly, The $\mathrm{R}^{2}$ and NSE for sediment yield calibration of SSW were 0.72 and 0.59 respectively and that for validation were 0.36 and 0.20 respectively. Likewise, $\mathrm{R}^{2}$ and NSE for TN calibration of the SSW were 0.38 and 0.31 respectively and that for validation were 0.37 and 0.37 respectively. Similarly, $\mathrm{R}^{2}$ and NSE for TP calibration of SSW were 0.50 and 0.31 respectively and that for validation were 0.76 to 0.71 respectively. The comparison of monthly observed and simulated streamflow, sediment yield, TN, and TP along with the calibration/validation statistics are shown in Figs. 2, 3, 4, and 5 respectively. Details of calibration and validation results for streamflow, sediment, TN, and TP at watershed scale (BSRW) was provided in Risal and Parajuli (2019).

\subsection{Effect of BMPs at Field Scale}

Average reduction in flow, sediment yield, TN, and TP by application of BMPs within the SSW is presented in Table 3.

\section{Stovall Sherard Watershed}

Check dam BMP reduced streamflow by less than $1 \%$, sediment yield by $5 \%$, TN by $15 \%$, and TP by $11 \%$ at the watershed outlet. Similarly, Tail water ponds reduced sediment yield by $5 \%$, TN by $16 \%$, and TP by $15 \%$. Nutrient management had no effect on streamflow, sediment yield and TN as most of the fields in the watershed are cultivated with soybean and nitrogen was not applied to the soybean field (Deibert et al. 1979). Reduction in fertilizer by $10 \%, 20 \%$ and $30 \%$ reduced TP by $3 \%, 6 \%$ and $10 \%$ respectively.

Table 2 Different tillage treatments applied to the SWAT along with tillage depth and mixing efficiency (Tripathi et al. 2005)

\begin{tabular}{lll}
\hline Tillage operation & Tillage depth $(\mathrm{mm})$ & $\begin{array}{l}\text { Mixing } \\
\text { Efficiency }\end{array}$ \\
\hline Conventional Tillage & 75 & 0.5 \\
Conservation Tillage & 40 & 0.25 \\
Zero Tillage & 10 & 0.05 \\
\hline
\end{tabular}




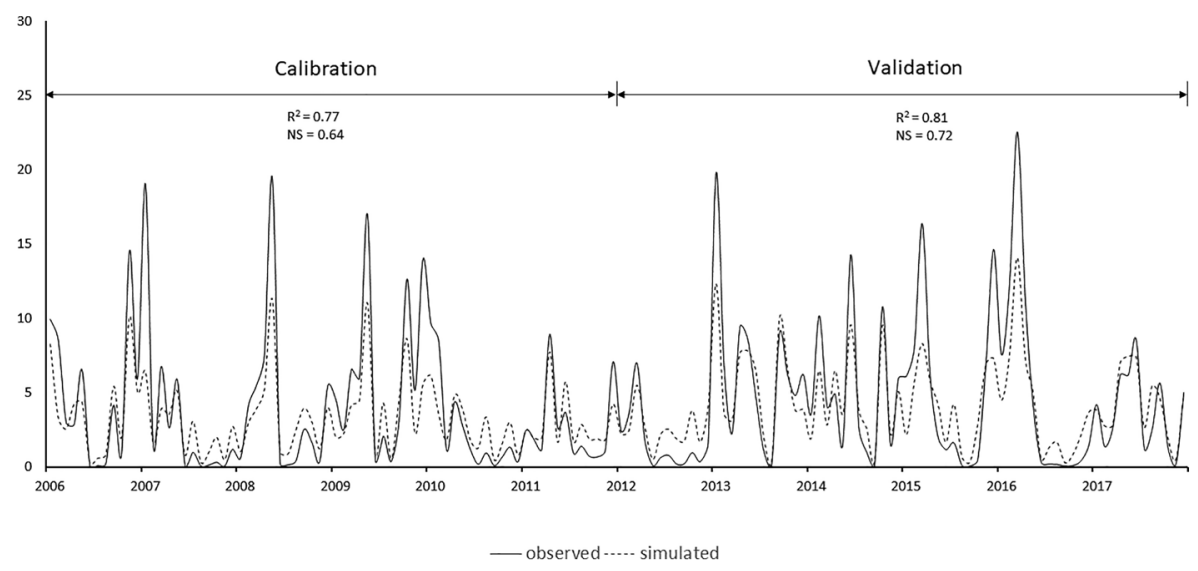

Fig. 2 Comparison of observed and simulated streamflow statistics at the Stovall Sherard Watershed during model calibration and validation

Application of VFS widths of 10, 20 and $30 \mathrm{~m}$ at the edge of agricultural fields reduced sediment yield by $9 \%, 11 \%$, and $12 \%$; TN by $71 \%, 88 \%$ and $99 \%$; and TP by $73 \%, 89 \%$ and $99 \%$ respectively. Both conservation and zero tillage reduced sediment yield by $1 \%$. On the other hand, conservation tillage increased TN by $10 \%$ and reduced TP by $2 \%$ while zero tillage increased TN by $25 \%$ and had no effect on TP as most of the fields in SSW are covered by soybean and soybean can accumulate phosphorus from soil, which may not be available to dissolve in runoff (Reddy et al. 1999).

\subsection{Effect of BMPs at the Watershed Scale}

Average reduction in streamflow, sediment yield, TN, and TP by application of BMPs at the BSRW is shown in Table 4.
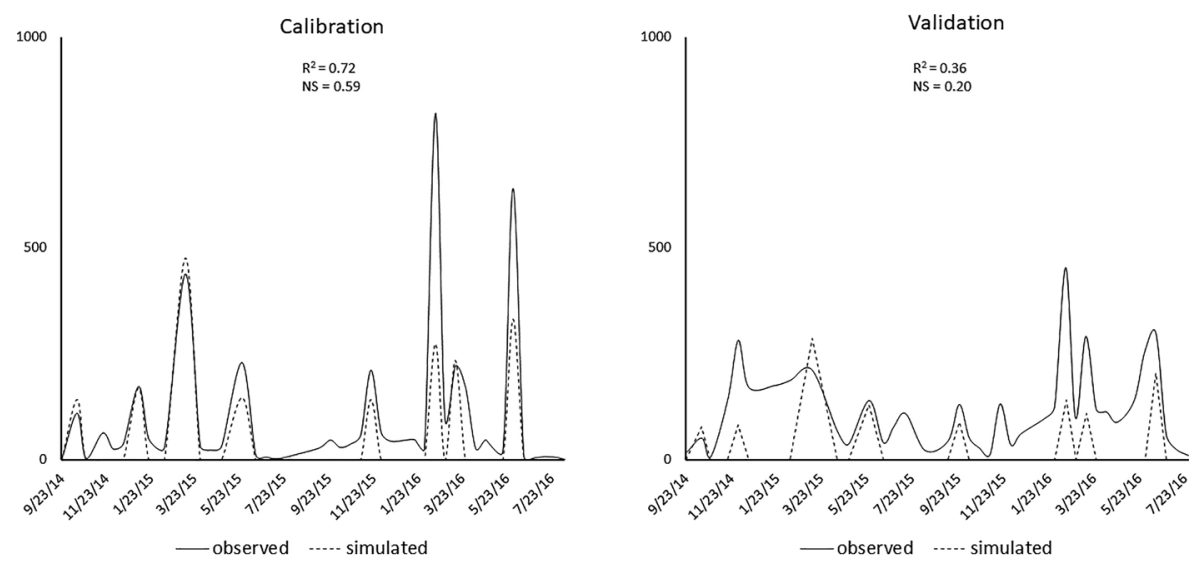

Fig. 3 Comparison of observed vs simulated sediment yield statistics at sites D and E of Stovall Sherard Watershed during model calibration and validation 

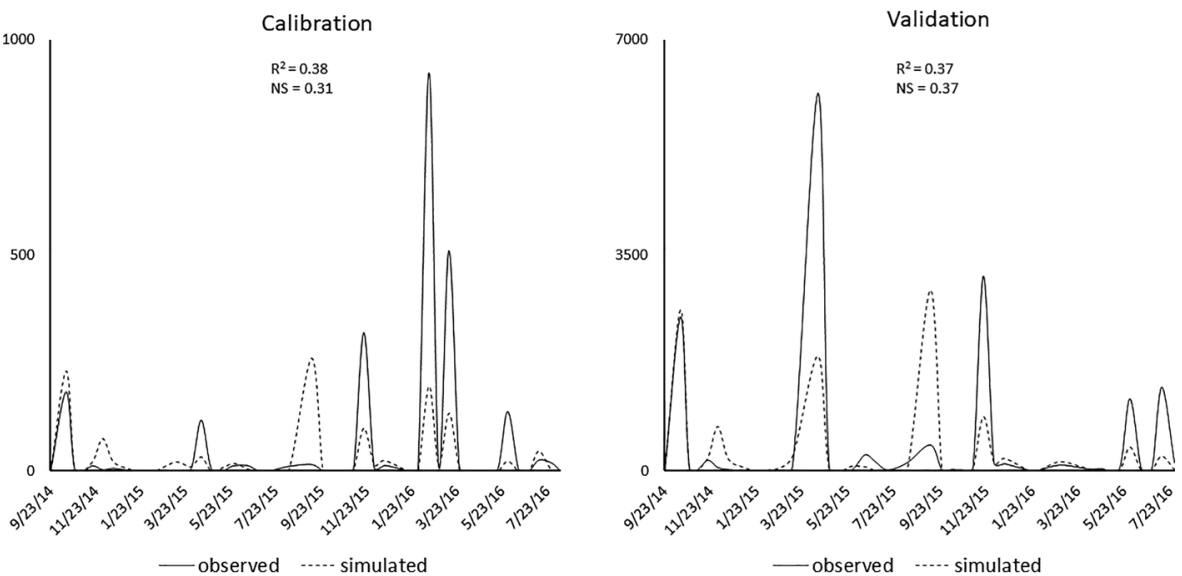

Fig. 4 The comparison of observed and simulated TN concentration at sites D and E of Stovall Sherard Watershed along with the calibration/validation statistics

Check dams at sub-basin outlets of the BSRW had no effect on streamflow but it reduced sediment yield, total nitrogen and total phosphorous at the outlet of the watershed by $12 \%$, $9 \%$ and $2 \%$ respectively. Tail water pond reduced sediment yield by $27 \%$, TN by $13 \%$ and TP by $3 \%$ at the outlet of the BSRW. Average reduction in TN and TP were proportional to the reduction in rate of fertilizer applied to the agricultural fields. Nutrient management had no effect on streamflow and sediment yield but had high effect on TN and TP. Reduction in 10\%, $20 \%$ and $30 \%$ of fertilizer application rate reduced $\mathrm{TN}$ by $22 \%, 24 \%$ and $26 \%$ and $\mathrm{TP}$ by $3 \%$, $6 \%$ and $8 \%$ respectively.

The VFS widths of 10, 20, and $30 \mathrm{~m}$ at the edge of agricultural fields reduced sediment yield by $12 \%, 33 \%$, and $38 \%$, TN by $29 \%, 74 \%$ and $87 \%$ and TP by $42 \%, 89 \%$ and $99 \%$
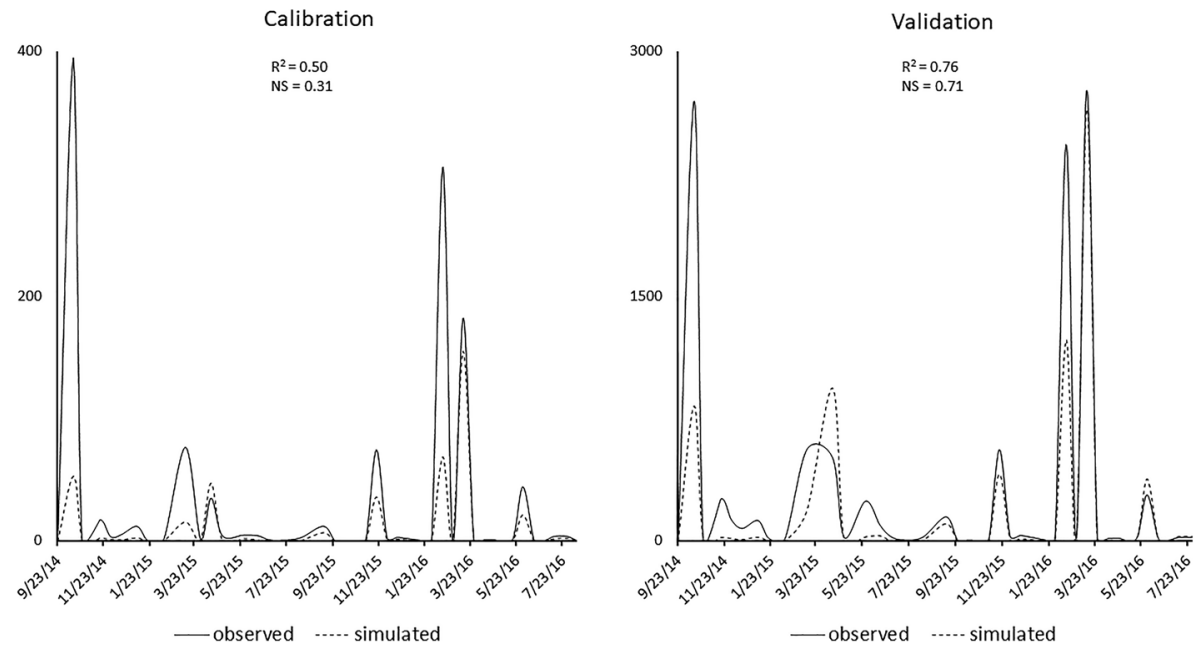

Fig. 5 The comparison of observed and simulated TP concentration at sites D and E of Stovall Sherard Watershed along with the calibration/validation statistics 
Table 3 Summary of the performance of BMPs in reduction of flow, sediment yield, TN and TP for Stovall Sherard Watershed

\begin{tabular}{|c|c|c|c|c|c|}
\hline BMP Operation & Detail & Flow $(\%)$ & $\begin{array}{l}\text { Sediment } \\
\text { yield }(\%)\end{array}$ & $\mathrm{TN}(\%)$ & $\mathrm{TP}(\%)$ \\
\hline Check dam & & 0 & 5 & 15 & 11 \\
\hline Tailwater pond & & 0 & 5 & 16 & 15 \\
\hline \multirow[t]{3}{*}{ Nutrient management } & $10 \%$ reduction in applied fertilizer & 0 & 0 & 0 & 3 \\
\hline & $20 \%$ reduction in applied fertilizer & 0 & 0 & 0 & 6 \\
\hline & $30 \%$ reduction in applied fertilizer & 0 & 0 & 0 & 10 \\
\hline \multirow[t]{3}{*}{ Filter strip } & 10-m width & 0 & 9 & 71 & 73 \\
\hline & 20-m width & 0 & 11 & 88 & 89 \\
\hline & 30-m width & 0 & 12 & 99 & 100 \\
\hline \multirow[t]{2}{*}{ Tillage management } & Conservation tillage & 0 & 1 & -10 & 2 \\
\hline & Zero tillage & 0 & 1 & -25 & 0 \\
\hline
\end{tabular}

Table 4 Summary of the performance of BMPs in reduction of flow, sediment yield, TN and TP for Big Sunflower River Watershed

\begin{tabular}{llllll}
\hline BMP Operation & Detail & Flow (\%) & $\begin{array}{l}\text { Sediment } \\
\text { yield (\%) }\end{array}$ & TN (\%) & TP (\%) \\
\hline Check dam & & 0 & 12 & 9 & 2 \\
Tailwater pond & & 0 & 27 & 13 & 3 \\
Nutrient management & $10 \%$ reduction in applied fertilizer & 0 & 0 & 22 & 3 \\
& 20\% reduction in applied fertilizer & 0 & 0 & 24 & 6 \\
& $30 \%$ reduction in applied fertilizer & 0 & 0 & 26 & 8 \\
Filter strip & $10-$ m width & 0 & 12 & 29 & 42 \\
& 20-m width & 0 & 33 & 74 & 89 \\
& $30-m$ width & 0 & 38 & 87 & 99 \\
Tillage management & Conservation tillage & 0 & 1 & -14 & -5 \\
& Zero tillage & 0 & 2 & -26 & -13 \\
\hline
\end{tabular}

respectively at the outlet of watershed. Conservation tillage and zero tillage reduced sediment yield by $1 \%$, and $2 \%$ respectively. Conservation tillage increased TN by $14 \%$ and TP by $5 \%$; while zero tillage increased TN by $26 \%$ and TP by $13 \%$ at the watershed outlet.

\section{Discussions and Conclusion}

BMPs applied in this study showed the least effect on streamflow reduction at both field and watershed scales as streamflow is estimated in SWAT using the SCS runoff curve numbers (CN2), which depends mainly on type of soil and land cover data layers but not much affected by management operations (Maharjan et al. 2018; Uribe et al. 2018). However, the BMP had high impact on reduction of sediment and nutrient loads. Among different BMPs, VFS was the most efficient practice in reducing sediment, TN and TP at both field 
and watershed scales. Previous studies on effect of VFS on water quality have also showed that it is an effective BMP that can reduce sediment yield by $35 \%$ and total phosphorous by $21 \%$ (Jang et al. 2017).

Similarly, tail water pond was more effective in reducing TP at field scale than at watershed scale. It was more effective in reduction of sediment yield (27\%) and TN (13\%) at watershed scale than at field scale (5\% and 2\%). Previous study showed that tail water pond was successful in reducing sediment yield by up to $20 \%$ (Ni and Parajuli, 2018). The ponds applied to other watershed scale model have reduced sediment yield by up to $58 \%$ (Zhang and Zhang 2011). The effectiveness of the tail water pond was dependent mainly on the retention time of the pond (Edwards et al. 1999).

Likewise, check dam was more suitable BMP for reduction of TN and TP at field scale and for the reduction of sediment yield at watershed scale. Previous study in the Huangfuchuan basin in China found reduction in runoff and sediment by $24 \%$ and $28 \%$ during 1990 to 1999 and $65 \%$ and $78 \%$ reduction during 2000 to 2012 after addition of several check dams (Li et al. 2017). Check dam was found an effective BMP for the retention of nutrients in the watershed along with the reduction in runoff and sediment yield (Mongil-Manso et al. 2019).

Similarly, nutrient management practice reduced TP up to $10 \%$ within the SSW but had no effect on sediment yield and TN because most of the fields in the SSW were cultivated with soybean, where fertilizer containing phosphorous were applied (Deibert et al. 1979). Maximum reduction in TN and TP by nutrient management at watershed scale were $26 \%$ and $8 \%$ respectively at the BSRW outlet. Nutrient management applied to the Haean highland agricultural watershed located in South Korea showed that it is an effective nutrient reduction method as it removed TN from $4.9 \%$ to $16.4 \%$; and TP from $0.7 \%$ to $7.9 \%$ (Jang et al. 2017).

Likewise, the application of conservation and zero tillage operation reduced sediment yield but increased TN and TP from both field scale and watershed scale. Increase in nutrient load was observed due to mixing of applied fertilizer, residual cover crops, and plant residues on the soil surface (Tripathi et al. 2005; Uribe et al. 2018). Conventional tillage thoroughly blends nutrients like nitrogen and phosphorous available on the surface of the soil and thus cannot be dissolved easily in the surface runoff after the occurrence of major rainfall event but conservational and zero tillage helps in dissolving these nutrients in surface runoff producing higher nutrient loads at watershed outlet. Several studies related to effect of different tillage operations on nutrient load have obtained similar results of higher nitrogen and phosphorous loads under conservation tillage than conventional tillage ( McDowell and McGregor 1980; Alberts and Spomer 1985; Tripathi et al. 2005).

Performance of BMPs at field and watershed scale had varying reduction rate for hydrology and water quality parameters such as streamflow, sediment, and nutrient loads. The sources of error may be associated with the resolutions of DEM, LULC data, and model parameters obtained during model calibration. $30 \mathrm{~m}$ resolution DEM was applied to the watershed scale model while $10 \mathrm{~m}$ resolution DEM was applied to the field scale model. The field scale model for the SSW was developed because the watershed scale BSRW model was not able to simulate the watershed process and management activities at field scale. Moreover, the BSRW with a drainage area of 10,500 square kilometers had comparatively higher variety of land use type, soil and slope than the SSW with a drainage area of 120 square kilometers. Likewise, field scale SWAT is calibrated for sediment yield and nutrient loads at small field plots whereas watershed scale SWAT was calibrated at the outlet of sub-basins that drains larger area than area of entire SSW. Similarly, crop land data obtained from USDA NAAS was applied to the watershed scale SWAT; whereas the 
LULC data layer obtained by reclassifying Landsat images from 2014 to 2018 was applied to the field scale because of its accuracy at small scale.

Both field and watershed scale SWAT can estimate the reduction potential of individual BMPs. Results obtained from this study will provide a broad idea to other modelers and watershed decision makers for water management by evaluating the effects of BMPs for reduction of surface runoff, sediment, and nutrient yields at both field and watershed scale.

Acknowledgements We would like to acknowledge the support of USDA/NIFA competitive grant award \# 2017-67020-26375, Bagley College of Engineering and College of Agriculture and Life Sciences at Mississippi State University, Yazoo Mississippi Delta Joint Water Management District, United States Geological Survey (USGS), and all our collaborators for providing necessary data for this study.

Authors Contributions AR developed models, analyzed model outputs, and drafted the manuscript.

PP developed the conceptual framework of research, obtained financial support for research, and reviewed the manuscript.

Funding Funding sources are mentioned.

Availability of Data and Materials Authors understand that journal encouraged data sharing and data citation.

\section{Declarations}

Ethical Approval Authors agreed to the ethical approval needed to publish this manuscript.

Consent to Participate Authors have consent to participate in the publication process.

Consent to Publish Authors agreed to publish this manuscript.

Competing Interests Authors don't have any competing interests.

Open Access This article is licensed under a Creative Commons Attribution 4.0 International License, which permits use, sharing, adaptation, distribution and reproduction in any medium or format, as long as you give appropriate credit to the original author(s) and the source, provide a link to the Creative Commons licence, and indicate if changes were made. The images or other third party material in this article are included in the article's Creative Commons licence, unless indicated otherwise in a credit line to the material. If material is not included in the article's Creative Commons licence and your intended use is not permitted by statutory regulation or exceeds the permitted use, you will need to obtain permission directly from the copyright holder. To view a copy of this licence, visit http://creativecommons.org/licenses/by/4.0/.

\section{References}

Abbaspour KC (2013) Swat-cup 2012. SWAT calibration and uncertainty program - A user manual. https:// swat.tamu.edu/media/114860/usermanual_swatcup.pdf

Alberts EE, Spomer RG (1985) Dissolved nitrogen and phosphorus in runoff from watersheds in conservation and conventional tillage. J Soil Water Conserv 40(1): 153-157. https://www.jswconline.org/ content/40/1/153

ArcSWAT (2019) Soil and Water Assessment tool software. https://swat.tamu.edu/software/arcswat/

Arnold JG, Kiniry JR, Srinivasan R, Williams JR, Haney EB, Neitsch SL (2012) Soil and water assessment tool input/output documentation version 2012. Texas Water Resource Institute, TR-439. https://swat. tamu.edu/media/69296/swat-io-documentation-2012.pdf

Bhandari AB, Nelson NO, Sweeney DW, Baffaut C, Lory JA, Senaviratne A, Pierzynski GM, Janssen KA, Barnes PL (2017) Calibration of the APEX model to simulate management practice effects on runoff sediment and phosphorus loss. J Environ Qual 46(6):1332-1340 
Borrelli P, Alewell C, Alvarez P, Anache JAA, Baartman J, Ballabio C, Bezak N, Biddoccu M, Cerdà A, Chalise D (2021) Soil erosion modelling: A global review and statistical analysis. Sci Total Environ 146494.https://doi.org/10.1016/j.scitotenv.2021.146494

Capel PD, Kathleen AM, Richard HC, Katia MG, Sheila EA, Nancy TB, Richard LJ (2018) Agriculture-a river runs through it: The connections between agriculture and water quality (Vol. 1433). Geological Survey. https://pubs.er.usgs.gov/publication/cir1433

Daggupati P, Douglas-Mankin KR, Sheshukov AY, Barnes PL, Devlin DL (2011) Field-level targeting using SWAT: Mapping output from HRUs to fields and assessing limitations of GIS input data. Trans ASABE 54(2):501-514

Dakhlalla AO, Parajuli PB (2015) Evaluation of the Best Management Practices at the Watershed Scale to Attenuate Peak Streamflow Under Climate Change Scenarios. Water Resour Manag 30(3):963982. https://doi.org/10.1007/s11269-015-1202-9

Dakhlalla AO, Parajuli PB, Ouyang Y, Schmitz DW (2016) Evaluating the impacts of crop rotations on groundwater storage and recharge in an agricultural watershed. Agric Water Manag 163:332-343. https://doi.org/10.1016/j.agwat.2015.10.001

Deibert EJ, Bijeriego M, Olson RA (1979) Utilization of 15N Fertilizer by Nodulating and Non-Nodulating Soybean Isolines. Agron J 71(5):717-723

Edwards CL, Shannon RD, Jarrett AR (1999) Sedimentation basin retention efficiencies for sediment, nitrogen, and phosphorus from simulated agricultural runoff. Trans ASAE 42(2):403-409

Gitau MW, Gburek WJ, Bishop PL (2008) Use of the SWAT model to quantify water quality effects of agricultural BMPs at the farm-scale level. Trans ASABE 51(6):1925-1936

Gyamfi C, Ndambuki JM, Salim RW (2016) Hydrological responses to land use/cover changes in the Olifants Basin. South Africa Water 8(12):588. https://doi.org/10.3390/w8120588

Jang SS, Ahn SR, Kim SJ (2017) Evaluation of executable best management practices in Haean highland agricultural catchment of South Korea using SWAT. Agric Water Manag 180:224-234

Kumar A, Kumar P, Singh VK (2019) Evaluating Different Machine Learning Models for Runoff and Suspended Sediment Simulation. Water Resour Manag 33:1217-1231. https://doi.org/10.1007/ s11269-018-2178-z

Li E, Mu X, Zhao G, Gao P, Sun W (2017) Effects of check dams on runoff and sediment load in a semiarid river basin of the Yellow River. Stoch Environ Res and Risk Assess 31(7):1791-1803

Li L, Wu K, Jiang E, Huijuan Y, Yuanjian W, Shimin T, Suzhen D (2021) Evaluating Runoff-Sediment Relationship Variations Using Generalized Additive Models That Incorporate Reservoir Indices for Check Dams. Water Resour Manag 35:3845-3860. https://doi.org/10.1007/s11269-021-02928-x

Lory JA (2018) Agricultural phosphorus and water quality University of Missouri-Columbia. https://hdl. handle.net/10355/69188

MAFES (2019) Mississippi State University Agricultural and Forestry Experiment Station (MAFES). http://mafes.misstate.edu/variety-trials/

Maharjan GR, Prescher AK, Nendel C, Ewert F, Mboh CM, Gaiser T, Seidel SJ (2018) Approaches to model the impact of tillage implements on soil physical and nutrient properties in different agroecosystem models. Soil Tillage Res 180:210-221. https://doi.org/10.1016/j.still.2018.03.009

Mateo-Sagasta J, Zadeh SM, Turral H, Burke J (2017) Water pollution from agriculture: a global review Food and Agricultural Organization. https://www.fao.org/3/i7754e/i7754e.pdf

McDowell LL, McGregor KC (1980) Nitrogen and phosphorus losses in runoff from no-till soybeans. Trans ASAE 23(3):643-648

Merriman KR, Russell AM, Rachol CM, Daggupati P, Srinivasan R, Hayhurst BA, Stuntebeck TD (2018) Calibration of a field-scale Soil and Water Assessment Tool (SWAT) model with field placement of best management practices in Alger Creek. Michigan Sustainability 10(3):851. https://doi. org/10.3390/su10030851

Mongil-Manso J, Díaz-Gutiérrez V, Navarro-Hevia J, Espina M, San Segundo L (2019) The role of check dams in retaining organic carbon and nutrients. A study case in the Sierra de Ávila Mountain range (Central Spain). Sci Total Environ 657:1030-1040

NAAS (2018) United States Department of Agriculture National Agricultural Statistics Service (USDA NASS). https://www.nass.usda.gov/

Neitsch SL, Arnold JG, Kiniry JR, Srinivasan R, Williams JR (2002) Soil and water assessment tool user's manual version 2000. Texas Water Resources Institute. https://swat.tamu.edu/media/1294/ swatuserman.pdf

Ni X, Parajuli PB (2018) Evaluation of the impacts of BMPs and tailwater recovery system on surface and groundwater using satellite imagery and SWAT reservoir function. Agric Water Manag 210:78-87. https:// doi.org/10.1016/j.agwat.2018.07.027 
NOAA NCEI (2019) National Oceanic and Atmospheric Administration National Centers for Environmental Information. https://www.ncdc.noaa.gov/

NRCS (1997) National Engineering Handbook: Irrigation Guide, part 652. US Department of Agriculture, Washington, DC, 852. https://directives.sc.egov.usda.gov/OpenNonWebContent.aspx? content=17837. wba

Ouyang Y (2012) A potential approach for low flow selection in water resource supply and management. J Hydrol 454:56-63. https://doi.org/10.1016/j.jhydrol.2012.05.062

Parajuli PB, Jayakody P, Sassenrath F, Ouyang Y, Pote JW (2013) Assessing the impacts of crop-rotation and tillage on crop yields and sediment yield using a modeling approach. Agric Water Manag 119:32-42

Preetha PP, Joseph N, Narasimhan B (2021) Quantifying Surface Water and Ground Water Interactions using a Coupled SWAT_FEM Model: Implications of Management Practices on Hydrological Processes in Irrigated River Basins. Water Resour Manag 35:2781-2797. https://doi.org/10.1007/ s11269-021-02867-7

Reddy DD, Rao AS, Takkar PN (1999) Effects of repeated manure and fertilizer phosphorus additions on soil phosphorus dynamics under a soybean-wheat rotation. Biol Fertil Soils 28(2):150-155

Ricci GF, D'Ambrosio E, De Girolamo AM, Gentile F (2022) Efficiency and feasibility of Best Management Practices to reduce nutrient loads in an agricultural river basin. Agric Water Manag 259:107241. https://doi.org/10.1016/j.agwat.2021.107241

Risal A, Parajuli PB (2019) Quantification and simulation of nutrient sources at watershed scale in Mississippi. Sci Total Environ 670:633-643. https://doi.org/10.1016/j.scitotenv.2019.03.233

Saleh A, Arnold JG, Gassman PW, Hauck LM, Rosenthal WD, Williams JR, McFarland AMS (2000) Application of SWAT for the upper North Bosque River watershed. Trans ASAE 43(5):1077-1087

Santhi C, Arnold JG, Williams JR, Dugas WA, Srinivasan R, Hauck LM (2001) Validation of the swat model on a large river basin with point and nonpoint sources. J Am Water Resour Assoc 37(5):1169-1188

Sharpley A, Wang X (2014) Managing agricultural phosphorus for water quality: Lessons from the USA and China. J Environ Sci 26(9):1770-1782

SSURGO (2020) Soil Survey Geographic Database, United States Department of Agriculture (USDA), Natural Resources Conservation Service (NRCS). https:/www.nrcs.usda.gov/wps/portal/nrcs/detail/soils/ survey/office/ssr12/tr/?cid=nrcs142p2_010596

Tripathi MP, Panda RK, Raghuwanshi NS (2005) Development of effective management plan for critical sub watersheds using SWAT model. Hydrol Process 19(3):809-826

Uribe N, Corzo G, Quintero M, van Griensven A, Solomatine D (2018) Impact of conservation tillage on nitrogen and phosphorus runoff losses in a potato crop system in Fuquene watershed, Colombia. Agric Water Manag 209:62-72

USGS (2020) United States Geological Survey. https://www.usgs.gov/

Waidler D, White M, Steglich E, Wang S, Williams J, Jones CA, Srinivasan R (2011) Conservation practice modeling guide for SWAT and APEX. Texas Water Resources Institute. https://swat.tamu.edu/media/ 57882/Conservation-Practice-Modeling-Guide.pdf

Zhang X, Zhang M (2011) Modeling effectiveness of agricultural BMPs to reduce sediment load and organophosphate pesticides in surface runoff. Sci Total Environ 409(10):1949-1958. https://doi.org/10. 1016/j.scitotenv.2011.02.012

Publisher's Note Springer Nature remains neutral with regard to jurisdictional claims in published maps and institutional affiliations. 